\title{
Perampasan Aset Tanpa Pemidanaan Dalam Perspektif Economic Analysis Of Law
}

\author{
Irwan Hafid \\ Magister Hukum Fakultas Hukum Universitas Islam Indonesia Yogyakarta Indonesia \\ Jln. Cik Di Tiro No. 1 Yogyakarta Indonesia \\ irwan.hafidz@gmail.com
}

\begin{abstract}
Indonesia currently does not explicitly regulate the seizure of assets without punishment in Indonesian laws and regulations. Existing regulations only regulate the seizure of assets through criminal proceedings. This study wants to examine how the urgency of regulating the concept of non-conviction based asset forfeiture in the legislation and its correlation to the return of state finances in the perspective of economic analysis of law. This research is normative juridical, that is carried out by reviewing or analyzing secondary data in the form of legal materials, especially primary legal materials, secondary legal materials, and tertiary legal materials. The results of this study concluded that the regulation on asset confiscation without punishment is still not comprehensive enough so that the ratification of the Asset Confiscation Bill is needed. In the perspective of economic analysis of the law, the ratification of the bill can minimize the number of perpetrators of hiding assets and the efficiency of law enforcement policy efforts, so that it can be oriented towards the effectiveness of recovering state financial losses.
\end{abstract}

Key words: Economics; seizure of assets; criminal; legal

\begin{abstract}
Abstrak
Indonesia saat ini tidak secara tegas mengatur perampasan aset tanpa pemidanaan dalam peraturan perundang-undangan di Indonesia. Regulasi yang ada hanya mengatur perampasan aset melalui proses pidana. Penelitian ini ingin mengkaji bagaimana urgensi pengaturan konsep perampasan aset tanpa pemidanaan (non-conviction based asset forfeiture) dalam peraturan perundang-undangan serta korelasinya terhadap pengembalian keuangan negara dalam perspektif analisa ekonomi terhadap hukum (economic analysis of law). Penelitian ini bersifat yuridis normatif, yakni dilakukan dengan cara mengkaji atau menganalisis data sekunder yang berupa bahan hukum terutama bahan hukum primer, bahan hukum sekunder, dan bahan hukum tersier. Hasil penelitian ini menyimpulkan bahwa pengaturan tentang perampasan aset tanpa pemidanaan masih belum cukup komprehensif sehingga dibutuhkan pengesahan RUU Perampasan Aset. Dalam perspektif analisa ekonomi terhadap hukum, pengesahan RUU tersebut dapat menimimalisir tingginya pelaku kejahatan penyembunyian aset dan efisiensi upaya kebijakan penegakan hukum, sehingga dapat berorientasi pada efektivitas pengembalian kerugian keuangan negara.
\end{abstract}

Kata-kata Kunci: Ekonomi; perampasan aset; pidana; hukum 


\section{Pendahuluan}

Penelitian ini dilatarbelakangi setidaknya oleh empat urgensi permasalahan mendasar. Pertama, perkembangan kejahatan yang semakin kompleks. Kemajuan peradaban manusia di berbagai bidang kehidupan tidak hanya memberi dampak yang positif terhadap perbaikan kualitas hidup, tetapi juga mengakibatkan dampak negatif dengan berkembangnya berbagai bentuk kejahatan. Misalnya terkait dengan kejahatan yang bertujuan untuk mendapat keuntungan ekonomis atau lebih dikenal sebagai tindak pidana dengan motif ekonomi. ${ }^{1}$ Tindak pidana ini awalnya bersifat konvensional seperti pencurian, penipuan dan penggelapan, namun kini semakin berkembang melibatkan pelaku yang terpelajar dan seringkali bersifat transnasional atau lintas negara (white colar-crime). ${ }^{2}$

Kedua, pengembalian aset negara belum menjadi strategi penegakan hukum. Menurut data Indonesia Corruption Watch (ICW) bahwa penindakan terhadap kasuskasus yang dijerat dengan tindak pidana pencucian uang masih sangat minim. Dari 313 perkara korupsi yang ditangani KPK periode 2016 hingga 2018, hanya 15 kasus korupsi yang sekaligus dikenakan pasal pencucian uang. ${ }^{3}$ Contoh nyata dari angka tersebut tercermin dalam putusan kasus korupsi proyek E-KTP yang melibatkan Mantan Ketua DPR RI, Setya Novanto. Dalam putusan tersebut, Setya Novanto dihukum 15 tahun penjara, denda Rp. 500.000.000,00, dicabut hak politik 5 tahun, dan uang pengganti sebesar US\$ 7.300.000,00 (Rp. 101.000.000.000,00), padahal total kerugian negara yang dikorupsi ialah sebesar Rp. 2.300.000.000.000,00.4

Ketiga, pentingnya pengaturan tentang perampasan aset tanpa pemidanaan secara lebih komprehensif dalam perundang-undangan di Indonesia. Beberapa ketentuan dalam hukum positif pada dasarnya telah mengatur kemungkinan untuk merampas aset hasil tindak pidana, tetapi hal tersebut hanya dapat

\footnotetext{
${ }^{1}$ Secara teoritis Pompe mendefinisikan tindak pidana sebagai suatu kelakuan yang bertentangan dengan hukum (onrechmatig of wederrechtelijk), yang diadakan karena pelanggar bersalah (aan schuld van de overtreder te wijten), dan yang dapat dihukum (strafbaar). Adapun Molejatno mendefinisikannya sebagai sebagai perbuatan yang dilarang oleh undang-undang dan adanya ancaman pidana bagi siapa yang melanggarnya. Sementara yang dimaksud tindak pidana ekonomi adalah tindakan kejahatan yang mempunyai motif dan/atau mempunyai pengaruh ekonomi terhadap kegiatan perekonomian, keuangan negara, serta dunia usaha. Seperti tindak pidana korupsi atau suap. Molejatno, Asas-Asas Hukum Pidana, Liberty, Yogyakarta, 2000, hlm. 54; Patricia Rinwigati, Tindak Pidana Ekonomi dalam RKUHP: Quo Vadis?, Aliansi Nasional Reformasi KUHP, Jakarta, 2016, hlm. 3

${ }^{2}$ Kejahatan kerah putih (white colar-crime) adalah kejahatan yang dilakukan oleh kaum elit, pengusaha, bankir, atau para pejabat yang mempunyai peran dan fungsi strategis atau akses kebijakan strategis melalui korupsi, kecurangan, dan penipuan yang sangat merusak serta menimbulkan korban yang bersifat massal. Jenis kejahatan ini selain menghasilkan banyak harta kekayaan sekaligus juga melibatkan banyak dana untuk membiayai peralatan-peralatan, sarana dan prasarana yang mendukung pelaksanaan tindak pidana tersebut. Frassminggi Kamasa, "Kejahatan Kerah Putih, Kontraterorisme, dan Perlindungan Hak Konstitusi Warga Negara dalam Bidang Ekonomi", Jurnal Konstitusi, Vol. 11, No. 4, 2014, hlm. 783

3 Rofiq Hidayat, "Kasus Setnov, Visi 'Asset Recovery' Belum Jadi Prioritas," dalam https:/ / www. bukumonline.com/berita/ baca/lt5d0dbe1380889/kasus-setnov-visi-asset-recovery-belum-jadi-prioritas/, diakses pada 21 Juli 2021.

${ }_{4}^{4}$ Putusan Pengadilan Negeri Jakarta Selatan Nomor: 130/Pid.sus-TPK/2017/PN.Jkt.Sel.
} 
dilakukan setelah pelaku tindak pidana terbukti di pengadilan secara sah dan meyakinkan melakukan tindak pidana. Padahal masih terdapat berbagai kemungkinan yang dapat menghalangi penyelesaian mekanisme penindakan seperti itu, misalnya pelaku kejahatan sakit kronis, meninggal, tidak ditemukannya bukti yang cukup, atau adanya halangan lain yang mengakibatkan perkaranya tidak bisa dilanjutkan dalam pemeriksaan di pengadilan. ${ }^{5}$

Keempat, pembahasan RUU Perampasan Aset yang cukup lama/alot. Hampir satu dekade pemerintah telah merumuskan RUU Perampasan Aset yang hingga kini belum dirampungkan. Secara formal RUU ini sebenarnya telah masuk dalam 189 RUU Prolegnas 2015-2019 serta dalam 248 RUU Prolegnas 2020-2024, tetapi pembahasannya tidak sekalipun muncul dalam daftar prioritas tahunan. ${ }^{6}$ Dengan kata lain, dalam lima tahun masa jabatan DPR RI Periode 2015-2019, RUU Perampasan Aset belum pernah menjadi prioritas untuk segera dibahas. Bahkan hingga periode tersebut berakhir dan dilanjutkan oleh DPR RI Periode 2020-2024, RUU Perampasan Aset juga belum disahkan. RUU tersebut sangat penting guna menjangkau perkembangan kejahatan yang begitu pesat, khususnya dalam hal mengembalikan kerugian keuangan negara melalui model perampasan aset tanpa pemidanaan di Indonesia.

\section{Rumusan Masalah}

Berangkat dari latar belakang masalah di atas, maka rumusan masalah dalam penelitian ini adalah: Pertama, bagaimana urgensi pengaturan konsep perampasan aset tanpa pemidanaan (non-conviction based asset forfeiture) dalam peraturan perundang-undangan di Indonesia? Kedua, bagaimana korelasi pengaturan konsep perampasan aset tanpa pemidanaan (non-conviction based asset forfeiture) terhadap pengembalian keuangan negara dalam perspektif analisis ekonomi terhadap hukum (economic analysis of law)?

\section{Tujuan Penelitian}

Adapun tujuan penelitian ini yaitu: pertama, untuk mengetahui urgensi pengaturan konsep perampasan aset tanpa pemidanaan (non-conviction based asset forfeiture) dalam peraturan perundang-undangan di Indonesia. Kedua, untuk mengetahui korelasi pengaturan konsep perampasan aset tanpa pemidanaan

5 Konteks pemberhentian kasus ini misalnya dapat dilihat dalam perkara yang melibatkan mantan Presiden Republik Indonesia, Soeharto. Majelis Hakim Pengadilan Negeri Jakarta Selatan pada 28 September 2000 menetapkan bahwa penuntutan perkara pidana terhadap Soeharto tidak dapat diteruskan dan sidang dihentikan. Ramelan, Naskah Akademik Rancangan Undang-Undang tentang Perampasan Aset Tindak Pidana, BPHN Kemenkumham RI, Jakarta, 2012, hlm. 5

${ }^{6}$ DPR RI, "Program Legislasi Nasional” dalam http:// www.dpr.go.id/ un/ prolegnas, diakses pada 10 Agustus 2021 
(non-conviction based asset forfeiture) terhadap pengembalian keuangan negara dalam perspektif analisa ekonomi terhadap hukum (economic analysis of law)?

\section{Metode Penelitian}

Penelitian ini merupakan penelitian hukum normatif yang mengkaji regulasi perampasan aset tanpa pemidanaan di Indonesia serta korelasinya terhadap pengembalian kerugian keuangan negara dalam perspektif analisa ekonomi terhadap hukum. Bahan hukum yang digunakan adalah bahan hukum primer, bahan hukum sekunder, serta bahan hukum tersier. Sementara pendekatan yang digunakan ialah pendekatan perundang-undangan (statute approach) dan pendekatan konsep (conseptual approach). Bahan hukum tersebut kemudian dikumpulkan dengan dua cara, yakni studi dokumen dan studi literatur. Temuan hasil penelitian yang diperoleh dari ketiga bahan hukum di atas, selanjutnya dianalisis secara deskriptif kualitatif melalui tiga alur kegiatan, yakni reduksi bahan hukum, penyajian bahan hukum, serta penarikan kesimpulan.

\section{Hasil Penelitian dan Pembahasan}

\section{Konsep Perampasan Aset Tanpa Pemidanaan}

Kemajuan teknologi dan informasi telah menciptakan kemudahan bagi pelaku tindak pidana, khususnya terkait dengan penyembunyian aset hasil kejahatan. Praktik ini telah berkembang sedemikian kompleks setidaknya dalam kurun waktu 10 tahun terakhir.7 Konstruksi hukum pidana yang dibangun di Indonesia cenderung masih bertujuan untuk mengungkap tindak pidananya, menemukan pelakunya, serta menghukumnya. Hukuman ini relatif hanya terbatas pada pengenaan sanksi pidana badan seperti penjara, sementara terhadap penyitaan dan perampasan aset hasil tindak pidana sepertinya masih belum menjadi bagian penting dalam sistem hukum pidana di Indonesia. ${ }^{8}$

Modus operandi untuk menyembunyikan aset hasil tindak pidana berkembang dengan sangat variatif, bahkan sudah melewati yurisdiksi antar

\footnotetext{
7 Marfuatul Latifah, "Urgensi Pembentukan Undang-Undang Perampasan Aset Hasil Tindak Pidana di Indonesia", Negara Hukum, Vol. 6, No. 1, 2015, hlm. 27

${ }^{8}$ Kecenderungan yang dibangun dalam penegakan hukum pidana Indonesia ialah memberikan efek jera melalui hukuman penjara. Jikalau ada pidana denda berupa pembayaran uang pengganti, terkadang masih bisa disubstitusikan lagi dengan kurungan badan (jika pelaku kejahatan tidak membayarnya). Sayangnya, adanya substitusi tersebut dapat menciptakan peluang bagi pelaku untuk memilih memperpanjang masa hukuman badan dibandingkan dengan harus membayar uang pengganti, karena lamanya substitusi kurungan badan tentu lebih ringan karena tidak melebihi ancaman hukuman maksimum pidana pokoknya. Hal itu tentu berdampak pada efektivitas perampasan aset hasil tindak pidana yang tidak maksimal. Hasil tindak pidana adalah harta kekayaan yang secara langsung maupun tidak langsung diperoleh dari suatu tindak pidana (Proceeds of crime shall mean any property derived from or obtained, directly or indirectly, through the commission of an offence). Adnan Topan Husodo, "Catatan Kritis atas Usaha Pengembalian Aset Hasil Tindak Pidana Korupsi, Jurnal Legislasi Indonesia, Vol. 7, No. 4, 2010, hlm. 584
} 
negara. Aset-aset yang dibawa keluar negeri seperti tergambar dalam kasus Gayus Tambunan yang merugikan negara Rp. 106.700.000,00 dan USD 18.000.000, dari jumlah itu hanya Rp. 2.081.000.000,00 yang disetor ke kas negara dan sisanya belum berhasil dikembalikan karena diduga masih tersimpan di luar negeri. Bahkan dalam kasus lainnya, Kejaksaan Agung mensinyalir aset tersangka kasus Jiwasraya tersimpan di 10 negara. ${ }^{9}$ Dalam konteks ini, penyempurnaan terhadap instrumen hukum perampasan aset tanpa pemidanaan sangat diperlukan guna mengatasi munculnya berbagai modus operandi dalam tindak pidana.

Perampasan aset tanpa pemidanaan atau disebut juga Non-Conviction Based (NCB) Asset Forfeiture adalah konsep pengembalian kerugian negara yang pertama kali berkembang di negara common law, seperti Amerika Serikat. Konsep ini bertujuan untuk mengembalikan kerugian negara yang ditimbulkan akibat tindak kejahatan tanpa terlebih dahulu menjatuhkan pidana pada pelakunya. ${ }^{10}$ Kategori aset yang dapat dirampas menggunakan metode NCB asset forfeiture adalah aset yang diperoleh secara langsung atau tidak langsung dari tindak pidana, termasuk yang telah dihibahkan atau dikonversikan menjadi harta kekayaan pribadi, orang lain, atau korporasi.

Secara prinsip terdapat 2 bentuk perampasan aset, yakni perampasan secara in personam dan perampasan secara in rem. ${ }^{11}$ Pertama, perampasan secara in personam merupakan tindakan yang ditujukan kepada seseorang secara personal atas kesalahannya melalui mekanisme hukum yang tersedia atau disebut juga sebagai perampasan melalui mekanisme hukum pidana. Tindakan tersebut harus dilakukan berdasarkan putusan peradilan pidana. Jaksa dalam hal ini harus membuktikan bahwa aset yang dirampas merupakan hasil atau sarana dari sebuah tindak pidana. ${ }^{12}$ Kedua, perampasan in rem, atau juga dikenal civil forfeiture, perampasan perdata, dan NCB asset forfeiture..$^{13}$ Pada intinya adalah gugatan dilakukan terhadap aset, bukan terhadap orang. Tindakan ini terpisah dari peradilan pidana, tetapi hanya menentukan bahwa aset telah tercemar oleh tindak pidana. ${ }^{14}$

\footnotetext{
9 Ade Mahmud, "Urgensi Penegakan Hukum Progresif untuk Mengembalikan Kerugian Negara dalam Tindak Pidana Korupsi”, Jurnal Masalah Hukum, Vol. 49, No. 3, 2020, hlm. 258

${ }^{10}$ Yunus Husein, Penjelasan Hukum tentang Perampasan Aset Tanpa Pemidanaan dalam Perkara Tindak Pidana Korupsi, Pusat Studi Hukum dan Kebijakan \& Pusat Penelitian dan Pengembangan Hukum dan Peradilan Mahkamah Agung RI, Jakarta, 2019, hlm. 6

${ }^{11}$ Barbara Vettori, Tough on Criminal Weakth Exploring the Practice of Proceeds from Crime Confiscation in the EU, Springer, Berlin, 2006, hlm. 8-11

12 Marfuatul Latifah, Op. Cit., hlm. 17-30

${ }^{13}$ Ibid

14 Pencemaran yang dimaksud disandarkan pada 'taint doctrine' dimana sebuah tindak pidana dianggap menodai aset atau properti yang digunakan atau didapatkan dari tindak pidana. David S. Romantz, "Civil Forfeiture and The Constitution: A Legislative Abrogation of Right and The Judicial Response: The Guilt of The Res", Suffolk University Law Review, Vol. 28, 1994, hlm. 390
} 
Dari dua jenis model perampasan aset tersebut terdapat persamaan sebagai berikut: pertama, bertujuan agar pelaku kejahatan tidak boleh mendapatkan keuntungan dari hasil kejahatan. Kedua, sebagai upaya untuk menimbulkan efek jera terhadap pelaku (preventif) agar aset tersebut tidak digunakan untuk tujuan kriminal lebih lanjut. ${ }^{15}$ Munculnya konsep NCB asset forfeiture tersebut dilatarbelakangi oleh pergeseran paradigma penegakan hukum yang berorientasi untuk menangkap pelaku (follow the suspect), berubah pada orientasi mengejar kerugian (follow the money). Hal ini menjadi penting karena tindak pidana yang bermotif ekonomi, seperti tindak pidana korupsi atau tindak pidana pencucian uang dapat menyebabkan kerugian negara.

Peraturan perundang-undangan yang ada saat ini dinilai belum secara komprehensif mengatur NCB asset forfeiture yang direkomendasikan oleh PBB dan lembaga internasional lainnya. ${ }^{16}$ NCB asset forfeiture digunakan apabila pengambilalihan aset tidak dapat dilakukan, karena pemilik aset meninggal, berakhirnya proses pidana, terdakwa bebas, penuntutan pidana terjadi tetapi pengambilalihan aset tidak berhasil karena asetnya baru diketahui, terdakwa tidak berada dalam batas jurisdiksi, nama pemilik aset tidak diketahui, serta tidak ada bukti yang cukup untuk mengawali tuntutan pidana. ${ }^{17}$

Meskipun NCB asset forfeiture populer di negara common law, konsep tersebut dapat juga diterapkan di negara civil law seperti di Indonesia, asalkan memperhatikan hal-hal penting seperti perampasan aset in personam sebisa mungkin masih tetap harus dikedepankan. Namun bila tidak memungkinkan, perampasan in rem bisa digunakan. Akan lebih baik jika perampasan in personam dan in rem dilakukan bersamaan. ${ }^{18}$ Selain itu, karena NCB asset forfeiture dilakukan dengan mekanisme peradilan perdata, padahal sebenarnya merupakan bagian dari penegakan hukum pidana, maka kriteria hakim yang memeriksa ialah hakim perkara perdata atau kombinasi hakim perdata dan hakim pidana.

\section{Perampasan Aset dalam Peraturan Perundang-Undangan}

Secara umum ketentuan mengenai perampasan aset tanpa pemindanaan sejalan dengan konvensi atau perjanjian internasional sebagai berikut: (i) Konvensi PBB Menentang Korupsi atau United Nation Convention Against

15 Theodore S. Greenberg, Stolen Asset Recovery, A Good Practices Guide for Non-Conviction Based Asset Forfeiture, The World Bank \& UNODC, Washington D.C., 2009, hlm. 18

${ }^{16}$ Misalnya dalam Pasal 54 angka 1 United Nations Convention against Corruption 2003, Pasal 12 United Nations Convention against Transnational Organized Crimes, serta dalam Financial Action Task Force. Ramelan, Naskah Akademik Rancangan..., Op. Cit., hlm. 196-197

${ }^{17}$ Ibid., hlm. 131

18 David S. Romantz, Op. Cit., hlm. 41 
Corruption 2003 (UNCAC); $1^{19}$ (ii) Konvensi PBB Menentang Kejahatan Transnasional Terorganisir atau United Nations Convention Against Transnational Organized Crimes (UN-CATOC);20 serta (iii) Standar Internasional di bidang pencegahan dan pemberantasan tindak pidana pencucian uang atau Financial Action Task Force (FATF). ${ }^{21}$ Upaya perampasan aset tanpa pemidanaan ini telah menjadi bagian penting untuk menekan tingkat kejahatan dalam penyembunyian aset hasil tindak pidana di berbagai negara, seperti di Inggris, Australia, Nigeria, Peru, Selandia Baru, dan Filipina. ${ }^{22}$

Pada prinsipnya juga terdapat banyak dasar hukum yang dapat digunakan untuk melakukan perampasan aset di Indonesia. Namun, tidak semua ketentuan tersebut mengatur perampasan aset tanpa pemidanaan. Bahkan ketentuan tersebut dikenal dengan beberapa terminologi yang berbeda-beda. Namun pada intinya merupakan ketentuan pengambilalihan barang yang berkaitan dengan tindak pidana, yang sebagian besar harus melalui proses peradilan, baik perdata maupun pidana. Beberapa aturan dan ketentuan terkait perampasan aset dalam perundang-undangan di Indonesia, meliputi:

${ }_{19}$ Pasal 54 angka 1. huruf (c) UNCAC 2003 dengan tegas meminta negara-negara: "Consider taking such measures as may be necessary to allow confiscation of such property without a criminal conviction in cases in which the offender cannot be prosecuted by reason of death, flight or absence or in other appropriate cases".

${ }^{20}$ Pasal 12 UN-CATOC menyatakan bahwa Negara-negara Anggota harus menerapkan langkahlangkah serupa di dalam sistem hukum dalam negerinya kearah pengembangan yang mungkin lebih luas selama diperlukan guna memungkinkan penyitaan atas: (a) Hasil-hasil kejahatan yang didapat dari pelanggaranpelanggaran yang dicakup oleh Konvensi ini atau nilai kekayaan yang berhubungan dengan hasi-hasil tersebut; dan (b) Kekayaan, perlengkapan atau peralatan-peralatan lain yang digunakan pada atau ditujukan bagi penggunaan dalam pelanggaran yang dicakup oleh Konvensi ini.

${ }^{21}$ Rekomendasi No. 3 FATF menyebutkan "Countries may consider adopting measures that allow such proceeds or instrumentalities to be confiscated without requiring a criminal conviction, or which require an offender to demonstrate the lawful origin of the property alleged to be liable to confiscation, to the extent that such a requirement is consistent with the principles of their domestic law".

22 Penerapan instrumen perampasan aset ini tergambar dalam praktik di berbagai negara: (i) Pemerintah Inggris pada tahun 2002 menetapkan Proceed of Crime Act, yang mengatur terkait perampasan hasil tindak pidana. Sejak diberlakukan pada tahun 2003, aparat penegak hukum di Inggris telah berhasil merampas sekitar 234 juta poundsterling atau setara dengan 4,38734 trilyun rupiah aset hasil tindak pidana; (ii) Pemerintah Australia pada tahun 2002 juga menetapkan Proceed of Crime Act. Ketentuan tersebut membuka kesempatan yang sangat luas bagi aparat penegak hukum untuk menyita dan merampas aset hasil tindak pidana; (iii) Pemerintah Selandia Baru pada tahun 2005 juga menetapkan Criminal Proceeds and Instruments Bill setelah melihat keberhasilan Australia dan Inggris menerapkan ketentuan yang serupa; (iv) Pemerintah Nigeria pada tahun 1998-2006 berhasil menyita dan merampas hasil tindak pidana korupsi yang dilakukan oleh Jendral Sani Abacha, mantan presiden Nigeria, dalam jumlah 800.000.000 dollar AS dari dalam negeri dan 505,5 juta dollar AS dari negara Swiss; (v) Pemerintah Peru selama kurun waktu 2000-2001 melakukan reformasi hukum secara fundamental (pengembalian aset korupsi). Sebagai hasilnya, pada tahun 2001 Peru menerima kembali 33 juta dolar AS dari Kepulauan Cayman, tahun 2002 menerima 77.500.000 dollar dari Swiss, serta 2004 menerima 20.000.000 dollar dari Amerika Serikat. Dana tersebut berasal dari hasil korupsi Vladimiro Montesinos, kepala intelejen polisi pada pemerintahan Presiden Alberto Fujimori; serta (vi) Pemerintah Filipina selama 18 tahun (antara 1986-2004) berhasil menyita dan merampas 624.000.000 dollar AS dari Swiss. Dana tersebut berasal dari hasil korupsi Ferdinand Marcos, mantan Presiden Filipina. Ramelan, Naskah Akademik Rancangan..., Op. Cit., hlm. 16-17 
1. Kitab Undang-Undang Hukum Pidana (KUHP). ${ }^{23}$

2. Undang-Undang No. 8 Tahun 1981 tentang Hukum Acara Pidana. ${ }^{24}$

3. Undang-Undang No. 31 Tahun 1999 tentang Tindak Pidana Korupsi sebagaimana telah diubah dengan Undang-Undang No. 20 Tahun 2001. ${ }^{25}$

4. Undang-Undang Nomor 8 Tahun 2010 tentang Pencegahan dan Pemberantasan Tindak Pidana Pencucian Uang (TPPU).

5. Undang-Undang Nomor 10 Tahun 1995 tentang Kepabeanan sebagaimana telah diubah dengan Undang-Undang Nomor 17 Tahun 2006.

6. Undang-Undang Nomor 35 Tahun 2009 tentang Narkotika.

7. Undang-Undang Nomor 32 Tahun 2014 tentang Kelautan.

8. Undang-Undang Nomor 31 Tahun 2004 tentan Perikanan sebagaimana telah diubah dengan Undang-Undang Nomor 45 Tahun 2009.

Ketentuan tersebut hanya sebagian contoh peraturan yang berkaitan dengan perampasan aset hasil tindak pidana, di luar itu masih banyak peraturan terkait perampasan aset sesuai kategorisasi tindak pidana, khususnya tindak pidana yang bermotif keuntungan ekonomi. Dari jumlah tersebut, regulasi yang secara tegas mengatur instrumen perampasan aset tanpa pemidaan hanya terdapat dalam beberapa aturan, seperti dalam Undang-Undang No. 8 Tahun 2010 tentang TPPU. Pengesahan NCB asset forfeiture dalam undang-undang a quo didasari oleh UNCAC 2003 yang telah di ratifikasi melalui Undang-Undang No. 7 Tahun 2006. Pasal 54 ayat (1) huruf c UNCAC mengharuskan semua negara pihak untuk mempertimbangkan mengambil tindakan yang dianggap perlu sehingga perampasan aset hasil korupsi dimungkinkan tanpa proses pidana dalam kasus yang tidak dapat dituntut, misalnya dengan alasan kematian, pelarian, dan lainlain.

Ketentuan tersebut kemudian ditegaskan dalam Pasal 67 ayat (2) UndangUndang No. 8 Tahun 2010 tentang TPPU. ${ }^{26}$ Namun demikian, secara teknis pengaturannya tidak begitu lengkap, sehingga dikeluarkanlah 'Peraturan Mahkamah Agung RI No. 01 Tahun 2013 tentang Tata Cara Penyelesaian Permohonan Penanganan Harta Kekayaan dalam Tindak Pidana Pencucian Uang atau Tindak Pidana Lain' untuk mengisi kekosongan hukum tersebut. Secara lebih komprehensif, perampasan aset tanpa pemidanaan pada prinsipnya telah

${ }^{23}$ Perampasan aset dalam KUHP dikenal dengan istilah perampasan barang tertentu, sebagaimana diatur dalam Pasal 10 KUHP. Dalam konteks itu, perampasan aset merupakan bentuk pidana tambahan yang dapat dijatuhi kepada pelaku tindak pidana.

${ }^{24}$ Perampasan aset menurut UU ini dapat diinterpretasikan sebagai penyitaan yang diatur dalam Pasal 1 angka 16 KUHAP atau dirampas untuk kepentingan negara yang diatur dalam Pasal 194 ayat (1) KUHAP.

${ }^{25}$ Ketentuan mengenai perampasan aset dikenal dengan perampasan barang sitaan, yang diatur dalam Pasal 18, Pasal 19, Pasal 38B, dan Pasal 38C UU Tipikor

${ }^{26}$ Pasal 67 ayat (2) UU TPPU: Dalam hal yang diduga sebagai pelaku tindak pidana tidak ditemukan dalam waktu 30 (tiga pulub) hari, penyidik dapat mengajukan permohonan kepada pengadilan negeri untuk memutuskan Harta Kekayaan tersebut sebagai aset negara atau dikembalikan kepada yang berhak. 
dirumuskan dalam RUU Perampasan Aset, ${ }^{27}$ namun, hingga kini RUU tersebut belum disahkan di DPR RI. Urgensi pengesahan RUU tersebut setidaknya didasari oleh beberapa hal berikut:

Pertama, konstruksi sistem hukum pidana di Indonesia belum menempatkan penyitaan dan perampasan hasil dan instrumen tindak pidana sebagai bagian penting dari upaya menekan tingkat kejahatan di Indonesia; Kedua, upaya pengembalian aset tindak pidana di luar negeri menjadi sulit untuk diimplementasikan karena belum adanya ketentuan yang sama, mengingat Indonesia belum mengesahkan RUU Perampasan Aset sebagaimana dikehendaki oleh UNCAC; Ketiga, peraturan perundang-undangan yang ada saat ini dinilai belum secara komprehensif dan rinci mengatur tentang perampasan aset yang terkait dengan tindak pidana, dan masih memiliki banyak kekurangan (loophole) jika dibandingkan dengan konsep NCB Asset Forfeiture yang direkomendasikan oleh PBB dan lembaga-lembaga internasional lainnya. ${ }^{28}$

\section{Perampasan Aset dalam Kajian Economic Analysis of Law}

Berbagai upaya penanggulangan kejahatan terus berkembang seiring dengan perkembangan kejahatan itu sendiri. Upaya menangkap pelaku kejahatan untuk kemudian dipenjarakan agar mendapatkan efek jera, berangsur-angsur mulai menemui kegagalan demi kegagalan, terutama bagi kejahatan yang terkait dengan upaya mencari keuntungan finansial secara ilegal. Belakangan, upaya menanggulangi kejahatan ini mulai bergeser pada tindakan mengejar keuntungan ilegal yang didapat (asset recovery), daripada hanya fokus pada pengejaran pelaku aktivitas ilegal itu sendiri. ${ }^{29}$

Perampasan harta hasil kejahatan sebenarnya berakar dari prinsip tidak boleh memberikan keuntungan bagi pelaku (crime should not pay) atau seseorang tidak boleh mengambil keuntungan dari aktivitas ilegal yang ia lakukan. ${ }^{30}$ Sementara dalam praktiknya, model perampasan aset yang yang diterapkan di Indonesia saat ini cenderung membutuhkan waktu pengungkapan kasus yang relatif lama. Perampasan aset dengan waktu yang lama tersebut memudahkan pelaku untuk bersiap-siap dalam menyembunyikan aset yang didapatkan

\footnotetext{
27 Pasal 1 angka 3 RUU Perampasan Aset Tindak Pidana: Perampasan Aset Tindak Pidana yang selanjutnya disebut Perampasan Aset adalah tindakan bukum yang dilakukan oleh negara untuk merampas Aset Tindak Pidana berdasarkan putusan pengadilan yang telab berkekuatan bukum tetap tanpa didasarkan pada penghukuman terbadap pelakunya.

${ }^{28}$ Ramelan, Naskah Akademik Rancangan..., Op. Cit., hlm. 18-19

29 Yudi Kistiana, Pemberantasan Tindak Pidana Pencucian Uang Perspektif Hukum Progresif, Thafa Media, Yogyakarta, 2015, hlm. 14-15

30 Refki Saputra, "Tantangan Penerapan Perampasan Aset Tanpa Tuntutan Pidana (Non-Conviction Based Asset Forfeiture) dalam RUU Perampasan Aset di Indonesia” Jurnal Integritas, Vol. 3, No. 1, 2017, hlm. $120-121$
} 
(bahkan masih saja mendapatkan keuntungan dari bunga aset tersebut). ${ }^{31}$ Dalam konteks ini tujuan awal dari perampasan aset adalah agar keuntungan yang diinginkan oleh pelaku menjadi tidak tercapai.

Di sisi lain, hasil kajian ICW dalam kurun waktu tahun 2018 menunjukkan bahwa terdapat sekitar 1.162 perkara korupsi yang tersebar di Pengadilan Negeri (926), Pengadilan Tinggi (208), dan Mahkamah Agung RI (28), dengan total kerugian negara sebesar Rp. 9.290.000.000.000,00. Angka tersebut hanya kerugian yang dikorupsi, belum termasuk biaya penegakan hukum korupsi atau biaya sejenis lainnya. Sementara vonis hakim untuk membayar uang pengganti dari kasus tersebut hanya sebesar Rp. 805.000.000.000,00 dan USD 3.000.000.32 Dengan kata lain, kerugian keuangan negara yang berhasil dikembalikan dari hasil penegakan hukum tindak pidana korupsi hanya sebesar $8,7 \%$.

Jika hal tersebut tidak segera direspon dan ditanggulangi dengan cepat, maka khawatir akan semakin memberikan dampak yang buruk bagi stabilitas perekonomian suatu negara, baik secara makro maupun mikro.33 Perampasan aset tanpa pemidanaan perlu didaya gunakan secara optimal guna menakan pengembalian kerugian aset negara secara lebih cepat dan efektif sesuai dengan prinsip analisa ekonomi terhadap hukum (economic analysis of law). Karenanya, pelaku tindak pidana dengan motif ekonomi tersebut diharapkan akan mempertimbangkan keuntungan dan kerugian yang didapatkan untuk tidak melakukan tindak pidana. Semakin mudah mereka melakukan kejahatan (minim biaya tetapi untung maksimal) maka mereka akan melakukan kejahatan, begitu juga sebaliknya.

Konsep awal kemunculan prinsip analisa ekonomi terhadap hukum ini paling tidak bermula dari tulisan Cesare Beccaria yang berjudul On Crimes and Punishments pada 1764. Menurutnya, penjatuhan sanksi pidana seyogyanya dirancang (designed) sampai pada level tertentu untuk mengeliminasi keuntungan yang didapat oleh pelaku. ${ }^{34}$ Prinsip analisa ekonomi atas hukum tersebut semakin berkembang setelah Garry Becker menghubungkannya ke dalam masalah kejahatan, diskriminasi rasial, dan lain sebagainya. ${ }^{35}$ Adapun korelasi atau hubungan analisa ekonomi terhadap hukum (ekonomi empiris) ini paling tidak memberikan tiga kontribusi penting.

\footnotetext{
${ }^{31}$ Marfuatul Latifah, Op. Cit., hlm. 23

32 Dylan A. Rachman, "ICW: Kerugian Negara Akibat Korupsi pada 2018 Capai 9,29 triliun" dalam bttps:/ / nasional.kompas.com/ read/2019/04/28/15294381/ icw-kerugian-negara-akibat-korupsi-pada-2018-capai-rp-929triliun?page $=$ all, diakses pada 10 Agustus 2021

33 Salman Luthan, Kebijakan Kriminalisasi di Bidang Keuangan, UII Press, Yogyakarta, 2014, hlm. 219

34 Mahrus Ali, "Penegakan Hukum Pidana yang Optimal (Perspektif Analisis Ekonomi Terhadap Hukum)", Jurnal Hukum, No. 2, Vol. 15, 2008, hlm. 224

35 Richard Posner, Economics Analysis of Law, Edisi Kelima, Aspen Law \& Business, New York, 1998, hlm
} 
Kontribusi ini meliputi:36 (i) ekonomi memberikan suatu model yang sederhana tentang bagaimana individu berperilaku di hadapan hukum, yang secara lebih khusus menganalisis bagaimana individu merespon kehadiran sanksi pidana. Kebanyakan dari kita melakukan yang terbaik terhadap apa yang bisa kita lakukan atau memaksimalkan keuntungan dalam melakukan aktivitas; (ii) prioritas utama dalam analisa ekonomi (empiris) adalah untuk membedakan antara hubungan dan sebab, karena manusia dalam berperilaku adalah rasional dengan tujuan-tujuan tertentu; serta (iii) ekonomi menyediakan sebuah metrik yang jelas di dalam mengevaluasi sukses tidaknya suatu kebijakan hukum pidana.

Secara umum dapat dikatakan bahwa prinsip utama yang digunakan untuk memahami analisa ekonomi atas hukum pidana adalah prinsip rasionalitas dan prinsip efisiensi. Prinsip rasionalitas mengandung suatu pengertian bahwa manusia di dalam melakukan suatu aktivitas tertentu, termasuk melakukan kejahatan, berpikir secara rasional dengan tujuan utamanya untuk memaksimalkan keuntungan yang diharapkan (maximizing the expected utility). ${ }^{37}$ Adapun prinsip efisiensi terkait dengan penghematan, pengiritan, ketepatan, atau pelaksanan sesuai dengan tujuan. Efisiensi berkaitan dengan tujuan dan sarana yang digunakan untuk mencapai tujuan. Jika sarana yang ingin dicapai membutuhkan lebih banyak biaya dibandingkan dengan tujuan yang ingin dicapai, maka hal itu dikatakan tidak efisien. ${ }^{38}$

Bertalian dengan itu, perampasan aset tanpa pemidanaan dalam perspektif economic analysis of law dapat dilihat dalam dua hal. Pertama, perspektif rasionalitas yang terkait dengan pelaku tindak pidana. Russel B. Korobkin mengemukakan empat tipe rasionalitas yang ada korelasinya dengan terjadinya kejahatan, yakni: (i) manusia adalah makhluk rasional yang akan memaksimalkan cara untuk mencapai tujuannya (a man is a rational maximizer of his ends); (ii) rasional dengan banyaknya keuntungan yang ingin dicapai (the expected utility); (iii) rasional dalam mewujudkan keuntungan berdasarkan kepentingan diri sendiri dan sarana yang digunakan akan disesuaikan dengan tujuan kepentingannya masing-masing (self interest); serta (iv) rasional dalam memaksimalkan kekayaan (the wealth maximization). 39

Jika konsep rasionalitas ini dikaitkan dengan hukum pidana, maka asumsinya adalah pelaku kejahatan merupakan mahkluk rasional ekonomis yang

${ }^{36}$ Mahrus Ali, "Penegakan Hukum..., Op. Cit., hlm. 225-226 hlm. 293

${ }^{37}$ Herbert Hovenkamp,"Rationality in Law and Economics”, George Washington Law Review, Vol. 60, 1992,

${ }^{38}$ Mahrus Ali, "Penegakan Hukum..., Op. Cit., hlm. 230

39 Thomas J. Miles, "Empirical Economics and Study of Punishment and Crime", University of Chicago Legal Forum, Vol. 237, 2005, hlm. 238 
akan menimbang biaya yang harus dikeluarkan dalam melakukan kejahatan dengan keuntungan apa yang akan didapat. Ketika keuntungan lebih besar dibandingkan dengan biaya yang dikeluarkan, maka pelaku akan melakukan kejahatan..$^{40}$ Sebaliknya, jika keuntungan yang didapat lebih kecil dari biaya yang harus dikeluarkan, pelaku kemungkinan akan mengurungkan niatnya untuk melakukan kejahatan. Dengan kata lain, para individu berperilaku secara rasional untuk memaksimalkan keuntugan yang mereka dapatkan (individuals behave rationally to maximize their utility).

Dalam konteks NCB Asset Forfeiture, perampasan aset tersebut penting dalam mengurangi hasrat pelaku untuk melakukan tindak pidana (deterrence) karena keuntungannya akan semakin kecil. Pelaku tindak pidana dengan motif ekonomi ini (misalnya seperti koruptor) pada dasarnya lebih takut miskin daripada hukuman badan atau bahkan hukuman mati. ${ }^{41}$ Jika harta, kekayaan, keuntungan, atau apapun itu yang terkait dengan aset hasil tindak pidana diambil, maka disaat itu pula secara rasionalitas 'nyawa' mereka habis, karena aset tindak pidana merupakan rantai terakhir dalam kejahatan. Bahkan dalam kaitannya dengan pencucian uang, perampasan aset ini merupakan bagian penting dalam efektivitas rezim anti pencucian uang. ${ }^{42}$ Dengan begitu, pelaku secara rasional diharapkan mendapatkan efek jera untuk tidak mengulanginya lagi. ${ }^{43}$

Kedua, perspektif efisiensi dalam kebijakan penegakan hukum. Dalam konteks analisa ekonomi terhadap hukum pidana, efisiensi berkaitan dengan dua hal: (i) apakah perbuatan-perbuatan yang ingin ditanggulangi dengan hukum pidana tidak banyak memerlukan biaya, sehingga keuntungan yang hendak diraih darinya lebih besar; serta (ii) apakah sanksi pidana yang dijatuhkan lebih besar/berat dibandingkan dengan keuntungan yang diraih pelaku dari melakukan perbuatan pidana. Jika sanksi pidana lebih berat dari biaya yang harus dikeluarkan oleh pelaku, dapat dipastikan bahwa pelaku akan menghindar untuk melakukan kejahatan.

Dalam konteks ini, analisa biaya dan keuntungan sangat penting dalam kaitannya dengan usaha menanggulangai kejahatan. Masalah penanggulangan kejahatan berkaitan erat dengan alokasi anggaran yang tersedia, seberapa banyak sumber daya yang harus dialokasikan untuk menanggulangi kejahatan, dan

\footnotetext{
${ }^{40}$ Ibid

${ }^{41}$ Christoforus Ristianto, "Pengamat: Koruptor Lebih Takut Miskin daripada Mati" dalam https:// nasi onal.kompas.com/read/2019/07/30/15344231/pengamat-koruptor-lebih-takut-miskin-daripada-mati, diakses pada 15 Agustus 2021

42 Hanafi Amrani, Hukum Pidana Pencucian Uang, UII Press, Yogyakarta, 2015, hlm. 248

${ }^{43}$ Hal tersebut sejalan dengan tujuan hukum pidana untuk menjera atau mencegah. Harapannya agar pelaku tersebut, baik sebagai individu maupun orang lain yang potensial menjadi penjahat, akan jera atau takut melakukan kejahatan karena melihat sanksi yang dijatuhkan kepadanya atau kecilnya keuntungan yang mungkin akan mereka nikmati. Didik E. Purwoleksono, Hukum Pidana, Airlangga University Press, Surabaya, 2014, hlm. 91
} 
seberapa besar keuntungan yang didapat atau kerugian negara yang dapat dikembalikan. ${ }^{44}$ Dengan demikian, penerapan NCB asset forfeiture diharapkan akan dapat meminimalisir penggunaan sumber daya aparat penegak hukum yang berlebihan (biaya tinggi), karena tidak terlalu mengedepankan proses peradilan yang cukup lama, sementara kerugian negara yang dapat dikembalikan relatif cukup besar.

Perampasan aset ini merupakan bagian dari bentuk sanksi keuangan (monetary sanction). Analisa ekonomi terhadap hukum dalam penerapan konsep perampasan aset tanpa pemidanaan, seharusnya sangat mencerminkan prinsip efisiensi dalam kebijakan penegakan hukum, karena relatif lebih sederhana. ${ }^{45}$ Namun demikian, untuk menentukan bahwa sanksi tersebut efisien dan dapat mencegah pelaku untuk tidak lagi melakukan kejahatan, maka terlebih dahulu harus dipastikan bahwa aset hasil tindak pidana dapat dilacak dengan baik, dan tersedianya instrumen hukum untuk menjangkau itu, dalam konteks ini pentingnya pengesahan RUU Perampasan Aset yang memuat konsep NCB asset forfeiture.

Pendekatan analisa ekonomi terhadap hukum (dalam kajian ini) hanya dapat mampu mencegah kejahatan yang berkaitan dengan ekonomi. Dengan kata lain, motif pelaku melakukan kejahatan adalah untuk mendapatkan keuntungan yang bersifat ekonomis, misalnya seperti tindak pidana korupsi, tindak pidana suap, atau bahkan tindak pidana pencucian uang. Adapun untuk kejahatan yang tidak bermotif ekonomi, perspektif analisa ekonomi terhadap hukum tidak dapat diterapkan. Hal ini disebabkan karena titik pijak untuk menganalisisnya sedikit banyak masih terkait dengan faktor-faktor biaya dan keuntungan yang akan didapat (cost and benefit principle).

\section{Penutup}

Berdasarkan uraian tersebut dapat disimpulkan bahwa pengaturan konsep perampasan aset dalam perundang-undangan di Indonesia dapat ditemukan

${ }^{44}$ Mahrus Ali., Op. Cit., hlm. 228

45 Dalam perspektif penegakan hukum pidana, seseorang yang terbukti melakukan tindak pidana akan diproses sesuai prosedur hukum acara pidana, yang dapat memakan waktu berbulan-bulan bahkan bertahuntahun. Dalam konteks itu, aka nada biaya penegakan hukum yang tidak sedikit, sementara tindak pidana belum tentu terbukti, bahkan jika terbukti belum tentu aset hasil tindak pidana dapat dirampas semuanya. Selain itu, pelaku harus melewati proses sanksi. Bentuk sanksi umumnya meliputi, sanksi pidana mati, pidana seumur hidup, pidana penjara, dan pidana denda. Dalam konteks analisa ekonomi, bentuk sanksi pidana yang paling efisien dan cocok digunakan dalam kaitannya dengan prinsip biaya dan keuntungan adalah pidana mati dan pidana denda. Sedangkan pidana penjara dilihat dari analisa ekonomi terhadap hukum kurang sesuai. Penggunaan sanksi pidana penjara dalam konteks ini pada kenyatannya memerlukan biaya sosial yang sangat tinggi (bigh social cost of imprisonement) dan harus ditanggung oleh negara. Biaya ini meliputi biaya langsung dari membangun suatu gedung penjara, pemeliharaannya, menggaji pegawai-pegawai yang bertugas di penjara, dan biaya kesempatan yang hilang dari produktivitas bagi mereka yang dipenjara. Belum lagi biaya hidup setiap orang yang dimasukkan ke penjara akibat perbuatan yang dilakukan. Robert Cooter dan Thomas Ullen, Law and Economics, Cetakan Ketiga, Eddison Wesley Longman, Inc., Amerika Serikat, 2000, hlm. 468 
dalam KUHP, KUHAP, UU Tipikor, UU TPPU, dan/atau UU sektoral lainnya. Namun undang-undang a quo tidak secara tegas mengatur perampasan aset tanpa pemidanaan, tetapi mengatur perampasan aset melalui proses pidana. Oleh karena itu sangat diperlukan pengesahan RUU Perampasan Aset yang memuat konsep NCB asset forfeiture sebagaimana diamanatkan oleh UNCAC 2003. Hal ini dikarenakan peraturan perundang-undangan yang ada belum secara komprehensif dan rinci mengatur tentang perampasan aset hasil tindak pidana, sehingga masih terdapat banyak kekurangan (loophole) yang perlu disempurnakan.

Adapun korelasi perampasan aset tanpa pemidanaan dalam perspektif economic analysis of law dapat dilihat bahwa tujuan yang ingin diraih pelaku adalah keuntungan yang sebanyak-banyaknya, maka untuk menanggulanginya dilakukan dengan cara mengambil kembali keuntungan yang dimiliki pelaku. Penggunaan mekanisme NCB asset forfeiture juga tidak memerlukan biaya yang besar, sementara keuntungan yang diperoleh cenderung lebih besar dari biaya penanggulannya. Dengan begitu, NCB asset forfeiture dapat lebih cepat, efisien, dan efektif dalam pengembalian kerugian keuangan negara.

Oleh karena itu, kebijakan penegakan hukum yang dibangun kedepan seharusnya tidak hanya fokus pada penghukuman pelaku tindak pidana, tetapi juga mempertimbangkan keuntungan dan kerugian (economic analysis of law) pengembalian aset dalam penegakan hukum. Instrumen hukum yang dapat digunakan misalnya UU No. 8 Tahun 2010 tentang TPPU serta Peraturan Mahkamah Agung No. 01 Tahun 2013. Akan tetapi, agar proses perampasan aset dapat berjalan lebih optimal, maka RUU Perampasan Aset yang memuat konsep NCB asset forfeiture harus segera disahkan.

\section{Daftar Pustaka}

\section{Buku}

Amrani, Hanafi, Hukum Pidana Pencucian Uang, UII Press, Yogyakarta, 2015.

Cooter, Robert, dan Ullen, Thomas., Law and Economics, Cetakan Ketiga, Eddison Wesley Longman, Inc., Amerika Serikat, 2000.

Greenberg, Theodore S., Stolen Asset Recovery, A Good Practices Guide for NonConviction Based Asset Forfeiture, The World Bank \& UNODC, Washington D.C., 2009.

Husein, Yunus., Penjelasan Hukum tentang Perampasan Aset Tanpa Pemidanaan dalam Perkara Tindak Pidana Korupsi, Pusat Studi Hukum dan Kebijakan \& Pusat Penelitian dan Pengembangan Hukum dan Peradilan Mahkamah Agung RI, Jakarta, 2019.

Kistiana, Yudi, Pemberantasan Tindak Pidana Pencucian Uang Perspektif Hukum Progresif, Thafa Media, Yogyakarta, 2015. 
Luthan, Salman, Kebijakan Kriminalisasi di Bidang Keuangan, UII Press, Yogyakarta, 2014.

Molejatno, Asas-Asas Hukum Pidana, Liberty, Yogyakarta, 2000.

Posner, Richard Economics Analysis of Law, Edisi Kelima, Aspen Law \& Business, New York, 1998.

Purwoleksono, Didik E., Hukum Pidana, Airlangga University Press, Surabaya, 2014.

Ramelan, Naskah Akademik Rancangan Undang-Undang tentang Perampasan Aset Tindak Pidana, BPHN Kemenkumham RI, Jakarta, 2012.

Rinwigati, Patricia, Tindak Pidana Ekonomi dalam RKUHP: Quo Vadis? Aliansi Nasional Reformasi KUHP, Jakarta, 2016.

Vettori, Barbara, Tough on Criminal Weakth Exploring the Practice of Proceeds from Crime Confiscation in the EU, Springer, Berlin, 2006.

Jurnal

Ade Mahmud, "Urgensi Penegakan Hukum Progresif untuk Mengembalikan Kerugian Negara dalam Tindak Pidana Korupsi", Jurnal Masalah Hukum, Vol. 49, No. 3, 2020.

David S. Romantz, "Civil Forfeiture and The Constitution: A Legislative Abrogation of Right and The Judicial Response: The Guilt of The Res", Suffolk University Law Review, Vol. 28, 1994.

Frassminggi Kamasa "Kejahatan Kerah Putih, Kontraterorisme, dan Perlindungan Hak Konstitusi Warga Negara dalam Bidang Ekonomi", Jurnal Konstitusi, Vol. 11, No. 4, 2014.

Husodo, Adnan Topan., "Catatan Kritis atas Usaha Pengembalian Aset Hasil Tindak Pidana Korupsi, Jurnal Legislasi Indonesia, Vol. 7, No. 4, 2010.

Herbert Hovenkamp, "Rationality in law and Economics", George Washington Law Review, Vol. 60, 1992.

Mahrus Ali, "Penegakan Hukum Pidana yang Optimal (Perspektif Analisis Ekonomi Terhadap Hukum)", Jurnal Hukum, No. 2, Vol. 15, 2008.

Marfuatul Latifah, "Urgensi Pembentukan Undang-Undang Perampasan Aset Hasil Tindak Pidana di Indonesia", Negara Hukum, Vol. 6, No. 1, 2015.

Refki Saputra, "Tantangan Penerapan Perampasan Aset Tanpa Tuntutan Pidana (Non-Conviction Based Asset Forfeiture) dalam RUU Perampasan Aset di Indonesia" Jurnal Integritas, Vol. 3, No. 1, 2017.

Thomas J. Miles, "Empirical Economics and Study of Punishment and Crime", University of Chicago Legal Forum, Vol. 237, 2005.

\section{Online}

DPR RI, “Program Legislasi Nasional” dalam http://www.dpr.go.id/uu/ prolegnas, diakses pada 10 Agustus 2021

Hidayat, Rofiq, "Kasus Setnov, Visi 'Asset Recovery' Belum Jadi Prioritas," dalam https://www.hukumonline.com/berita/baca/lt5d0dbe1380889/kasus-setnov--visiasset-recovery-belum-jadi-prioritas/, diakses pada 21 Juli 2021 
Rachman, Dylan A., "ICW: Kerugian Negara Akibat Korupsi pada 2018 Capai 9,29 triliun" dalam https://nasional.kompas.com/read/2019/04/28/15294381 /icw-kerugian-negara-akibat-korupsi-pada-2018-ca pai-rp-929-triliun?page=all, diakses pada 10 Agustus 2021.

Ristianto, Christoforus., "Pengamat: Koruptor Lebih Takut Miskin daripada Mati" dalam https://nasional.kompas.com/read/2019/07/30/15344231/pengamatkoruptor-lebih-takut-miskin-daripada-mati, diakses pada 15 Agustus 2021

\section{Putusan}

Putusan Pengadilan Negeri Jakarta Selatan Nomor: 130/Pid.susTPK/2017/PN.Jkt.Sel.

Peraturan Mahkamah Agung RI No. 01 Tahun 2013 tentang Tata Cara Penyelesaian Permohonan Penanganan Harta Kekayaan dalam Tindak Pidana Pencucian Uang atau Tindak Pidana Lain

\section{Perundang-Undangan}

Financial Action Task Force

RUU Perampasan Aset Tindak Pidana

United Nations Convention against Corruption 2003

United Nations Convention against Transnational Organized Crimes

Undang-Undang Nomor 8 Tahun 2010 tentang Pencegahan dan Pemberantasan Tindak Pidana Pencucian Uang (Lembaran Negara Republik Indonesia Tahun 2010 Nomor 122, Tambahan Lembaran Negara Republik Indonesia Nomor 5164) 